\title{
SENSITIVITY OF THE SPEED EVALUATION TESTS OF CARRYING THE BALL IN YOUTH SOCCER PLAYERS
}

\author{
Bojan Rakojević, Bojan Leontijević, Aleksandar Janković \\ University of Belgrade, Faculty of sport and physical education
}

\begin{abstract}
This research is aimed at examining sensitivity of the speed evaluation tests while carrying the ball. The research included 76 male examinees, aged 17 years (+/- 6 months), who were divided into two qualitatively different subgroups. For determining the speed while carrying the ball, the tests of $M$ type of carrying the ball between cones and slalom ball carrying with a pass were performed. The obtained results proved that the examinees from the group of more successful soccer players (Group 1) scored better on the applied tests when compared to the results of the group consisting of the soccer players from lower ranked clubs and who are not national team members (Group 2). High values of the result homogeneity in the two groups (for the Groups 1 and 2 it was $75 \%$ and $68.75 \%$ respectively) lead to the conclusion that this ability is essential characteristics of young soccer players. The coefficient of discrimination of 0.269 for the results of $M$ type test and 0.197 for the results of the test of carrying the ball with a pass indicate that the results of the two tests provide possibility to qualitatively distinguish youth players. Therefore, it can be concluded that as a technical element, carrying the ball significantly affects the quality of players' performance.
\end{abstract}

Key words: SOOCER /SOCCER TECHNIQUE /CARRYING THE BALL /SPEED /YOUTH SOCCER

\section{INTRODUCTION}

Technical abilities of soccer players play essential role in the process of identification and selection of players, in training process planning, tactical formation establishing, determination of training and competition aims etc. (Abbott, Button, Pepping, \& Collins, 2005; Bompa, 2000). Consequently, they rank among the essential soccer skills which, if not improved, can limit manifestations of morphological, motor and functional potentials of soccer players (Aleksić, \& Janković, 2006). Although the period adolescence is favourable for adoption of new knowledge and skills, it is also extremely unstable, because, affected by growth, it can result in damage to coordination or losing of some already acquired skills. Therefore, improvement of technique is a primary task during the entire training process with young players. Almost all leading schools of soccer in their training programs focus on development of speed and technique as major abilities for the players selection process both for a specific role in a team and for establishment of the level of playing. Ajax academy of soccer, as one of the most recognized schools of soccer, in its training process applies the TIPS principle (technique, intelligence, personality, speed), in which besides personality character and intelligence of playing, development of technique and speed is prioritized (Bangsbo, 2003).

Carrying the ball is an element of soccer technique that is applied when a player cannot find a satisfying solution to play the ball, when he is taking it out of the penalty area, when he wants to conceal his intention prior to playing the ball, when he starts a swerve, when he overruns the opponent once the swerve is over ( $\mathrm{Ra}$ dosav, Molnar, \& Smajić, 2003). During the game, active time of a player with the ball is only a few minutes. The major part of this period is reserved for carrying the ball which can be rectilinear or curvilinear. By analysing technical activity of players during the game it was observe that better teams spend less time carrying the ball which can be explained by better tactical formation of play, more efficient movement of players without the ball and better overview of play (Hoff, Wisloff, Engen, Kemi, \& Helgerud, 2002). During the

164 Correspondence to: Aleksandar Janković, University of Belgrade, Faculty of Sports and Physical Education, 156 Blagoja Parovica Str, 11030 Belgrade; e-mail: aleksandar.jankovic @fsfv.bg.ac.rs 
game, a player carrying the ball covers the distance between 119-286 meters or $1.2-2.4 \%$ of the overall covered distance (Di Salvo, Baron, Tschan, Calderon Montero, \& Pigozzi, 2007). During one game a player passes with the ball at his feet $0,5-3 \%$ of the overall covered distance while ball possession per a player is from 0.3 to 3.1 minute (Jukić et al., 2007). By analysing soccer games it was observed that playing position and tactical tasks determine the frequency of manifestation of certain tactical elements. Soccer players who have ability to carry the ball fast impose as the middle field or side players. The greatest number of ball carrying is realized by defensive linkmen (11.78) who, by touching the ball more try to find the most efficient solution in the game while the least number of ball carrying is realized by the central defence players (Janković, \& Leontijević, 2009). While the aforesaid studies are related to senior teams, there are only few studies with this type of match analyses for youth players. During the match the teams run over approximately the same distance with similar medium running speed while more significant differences are noticed in quantity and quality of the use of technical elements. The research led to the conclusion that winning teams realize significantly more kicks which corroborates the importance of technical elements and its position in play (Grant, Williams, \& Reilly, 1999; Zubillaga, \& Gorospe, 2007).

As the anticipated research is of empirical-research character, the research problem is clearly defined and formulated so as to determine the level of significance of technical abilities in the context of their influence on the quality of soccer teams' play.

The key issue and the entire problem orientation of this research, is related to examination of the sensitivity of the speed evaluation tests of carrying the ball (carrying the ball between the cones or with a pass). It is expected that the research results contribute to solving the problem as for the importance and influence of technical abilities on quality of play of the youth soccer players, as well as to the increase of efficiency of the training programs in the part that refers to the development of technique in players. Additionally, the obtained results should give an answer about those technical skills that make the greatest qualitative difference between soccer players of differently ranked teams.

The subject of this research are technical abilities of the young soccer players. The assessment of technical abilities from the field of specific soccer speed will give an answer to the question whether the speed evaluation tests of carrying the ball were discriminative in the context of qualitative differentiation of young soccer players.

The paper is aimed at establishing the level of technical abilities of the young soccer players of different level of successfulness. In other words, the aim of the paper is to establish technical abilities in context of distinguishing successful and less successful soccer players and to examine sensitiveness of specific tests of carrying the ball in soccer.

\section{METHOD}

\section{Participants}

The research included 76 participants, divided into two groups, Group 1 of 44 male respondents and Group 2 of 32 male respondents, aged 17 years (+/6 months) who had been included in soccer training process for at least three years. The first subsample (Group 1) consisted of the players from more successful teams while the second subsample (Group 2) consisted of the players from less successful teams. The criterion of successfulness was established based on the teams' ranking in the ongoing championship, number of the national team players who play in the U-21 or U-19 teams, tradition of youth schools and success of the senior teams of these clubs.

\section{Sample of variables}

The sample of variables consisted of the variables regarding motor abilities of soccer players, realized by application of the two different tests for evaluation of specific soccer speed of carrying the ball. For establishment of the speed of carrying the ball the tests of carrying the ball between cones ( $M$ type of carrying the ball) and slalom ball carrying with a pass were performed. The reliability of these tests was confirmed by their usage in several relevant papers from the field of soccer which are acknowledged on global level (Rosch et al., 2000.; Malina et al., 2005).

In order to examine the influence of specific soccer tests on the speed variables, the following dependant variables were defined:

- M type of carrying the ball between cones (vdlp), (expressed in seconds),

- Slalom ball carrying with a pass (vdlpd) (expressed in seconds). 
The independent variables were:

- The dimensions of the set obstacle courses for the speed evaluation tests of carrying the ball.

\section{Measurement protocol}

All the tests were performed on the soccer fields with synthetic surface and the examinees performed all the tests in soccer boots. All the tests were performed by a standard size soccer ball (size 5). For this research, we have used the photo cells of the latest generation (Smart speed system, Australia) used to establish time necessary for performance of the tests of carrying the ball.

The test of slalom ball carrying with a pass was performed when a subject carried the ball as fast as possible between 4 cones, and after that he shot in the direction of bench so as to rebound the ball in order to continue carrying it in the direction of target. The starting line was at the same time the finish line. All cones were set in a line, so that the first cone was placed on the start line and the next three at the distance of $2.25 \mathrm{~m}$ each. The 1.2 -meter wide bench was placed at 9 meters form the start line.

The test of $M$ type of carrying the ball was performed in a $9 \times 9$ - meter square, so that four cones were placed in the square angles, and the fifth cone was put at $4.5 \mathrm{~m}$ between the first and the last cone. Such placed cones were in the form of the letter "M“, which was at the same time the path of the ball carrying. The aim of both tests was to perform it as fast as possible.

Prior to the testing, all the examinees performed a 15-minute warm up in order to avoid possible muscle pull or other injuries that could occur while performing the movement task. After the 15-minute warm up, the players performed the tests aimed at familiarization with the tests, for 10 minutes, at medium performance speed. Besides the respondents the testing included two measurers who controlled test performance and recorded the achieved results. During the main testing each participant performed the movement task three times.

\section{Data processing}

Evaluations of the examinees' speed of carrying the ball have parametric features and therefore were analysed by parametric procedures. Result processing was done by a multivariate analysis (MANOVA) and discriminant analysis together with descriptive parameters, mean value, standard deviation (Sd), minimum and maximum of all the values, coefficient of variation $(\mathrm{Cv})$, conficence interval, measures of skewness and kurtosis. The applied univariance procedures included ANOVA, t-test and Roy's test. All statistical test were processed by using the SPSS 17.0 program (SPSS INC Chicago, IL)

\section{RESULTS}

Central and dispersive parameters, asymmetry measures and kurtosis in evaluation of participants' carrying the ball represent the groups and indicate a possibility of application of parametric procedures.

Table 1. Central and dispersive parameters and measures of asymmetry and kurtosis of the evaluation of carrying the ball of the Group 1 respondents

\begin{tabular}{lccccccccccc}
\hline & M & SD & Er & Min & Max & KV & IP & SK & KU & P \\
\hline Vdlp & 10.56 & .31 & .05 & 9.9 & 11.2 & 2.96 & 10.46 & 10.65 & -.07 & -.50 & .890 \\
Vdlpd & 5.64 & .47 & .07 & 5.0 & 6.9 & 8.34 & 5.50 & 5.79 & .60 & -.22 & .798 \\
\hline
\end{tabular}

(vdlp - M type of carrying the ball between cones; vdlpd - slalom ball carrying with a pass; M - mean value; SD - standard deviation; Er -standard error; Min - minimal value; Max - maximal value; KV - Coefficient of variation; IP - relation interval; Sk - skewness; KU - kurtosis)

When observing the Group 1 testing results, it can be seen that minimal ( $\min$ ) and maximal (Max) values results of carrying the ball evaluation indicate that the values are within the expected range (Table 1). Values of the coefficient of variation (KV) indicate to homogeneity of results of the Group 1, for both applied tests (vdlp $=2.96$ and vdlpd $=8.34$ ). The results further showed that the distribution of the results is negatively asymmetrical which means that the curve of the distribution of the results is towards higher values, i.e., that there are more worse results with regard to the normal distribution in the test of carrying the ball with a pass (vdlpd - .60). On the other side, in the test of $M$ type of carrying the ball (vdlp) the distribution of the results 
is positively asymmetrical which means that the distribution curve of the results is towards lower values, i.e. that there are more better results with regard to the normal distribution (.07). Negative kurtosis value $(\mathrm{ku})$ indicate that the curve is flattened in the two speed evaluation tests of carrying the ball (vdlp $=-.50$; vdlpd $=-.22$ ). Distribution of values mostly varied within normal distribution (p) in the test of $M$ type of carrying the ball (vdlp $=.89)$ and in the test of slalom ball carrying with a pass (vdlpd $=.80)$.

Table 2. Central and dispersive parameters and measures of asymmetry and kurtosis of the assessment of carrying the ball of the Group 2 respondents

\begin{tabular}{lccccccccccc}
\hline & M & SD & Er & Min & Max & KV & \multicolumn{2}{c}{ IP } & SK & KU & P \\
\hline vdlp & 11.10 & .55 & .10 & 10.1 & 12.1 & 4.92 & 10.90 & 11.29 & .02 & -.82 & .977 \\
vdlpd & 6.26 & .62 & .11 & 5.1 & 7.4 & 9.94 & 6.04 & 6.49 & -.05 & -.79 & .993 \\
\hline
\end{tabular}

(vdlp - M type of carrying the ball between cones; vdlpd - slalom ball carrying with a pass; $\mathrm{M}$ - mean value; SD - standard deviation; Er -standard error; Min - minimal value; Max - maximal value; KV - Coefficient of variation; IP - relation interval; Sk - skewness; KU - kurtosis)

Minimal (min) and maximal (Max) values results of the speed evaluation tests of carrying the ball of the respondents from the Group 2 indicate that the values are within the expected range (Table 2). Values of the coefficient of variation (KV) indicate to homogeneity of results of the Group 2. In the tests of $M$ type of carrying the ball (vdlp) (4.92) and slalom ball carrying with a pass (vdlpd) (9.94). lowered values of skewness (sk) indicate that distribution is positively asymmetrical, which means that the results distribution curve is towards lower values, i.e., that there are more better results compared to normal distribution in the test of carrying the ball with a pass (vdlpd) (-.05). The skewness values (Sk) indicate that distribution is not asymmetrical in the $M$ type of carrying the ball (vdlp) (.02). Negative values of kurtosis $(\mathrm{Ku})$ indicate that the curve is flattened in the two speed evaluation tests of carrying the ball (vdlp $=-.82$; vdlpd $=-.79)$. Distribution of values mostly varied within normal distribution $(\mathrm{p})$ in the two speed evaluation tests of carrying the ball (vdlp = .98; vdlpd = .99).

Based on the multivariate analysis of the obtained results it can be concluded that there is a statistically significant difference between the two groups of respondents $(\mathrm{p}=.000)$. By discriminative analysis for the synthetized results of the two speed evaluation tests of carrying the ball, it was concluded that there is a significant difference and clearly defined limit between the groups of respondents compared to the results of the speed evaluation tests for $M$ type of carrying the ball (vdlp) and carrying the ball with a pass $(\mathrm{p}=.000)$.

The coefficient of discrimination indicates that the greatest contribution to discrimination between the two groups, when compared to the results of the speed evaluation tests of carrying the ball in $M$ type of carrying the ball .269 (vdlp) while the coefficient was the same for the test of carrying the ball with a pass 197 (vdlpd).

Table 3. Features of the groups of respondents according to the results of the speed evaluation tests of carrying the ball ${ }^{*}$ - significantly higher, ${ }^{1}$ number from the number of modalities of the groups it is higher)

\begin{tabular}{lccc}
\hline & Group 1 & Group 2 & c.disc. \\
\hline M type of carrying the ball & lower & higher $^{* 1}$ & 57.725 \\
Ball carrying with a pass & lower & higher $^{* 1}$ & 42.275 \\
\hline
\end{tabular}

Based on the analysis of the results of the speed evaluation tests of carrying the ball by the respondents it can be said that:

- the results of the Group 1 of the $M$ type of carrying the ball (vdlp) and the test of carrying the ball with a pass (vdlpd) indicate that this group has features of lower values of the achieved results which means that this group results are characterized by better scores,

- the results of the Group 2 of the $M$ type of carrying the ball (vdlp) and the test of carrying the ball with a pass (vdlpd) indicate that this group has features of higher (higher ${ }^{*}$ ) values of the achieved 
results which means that this group results are characterized by worse scores.

The results showed also that the defined features of the Group 1 are possessed by 33 out of 44 respondents who belonged to this group, which indicated to homogeneity of $75.0 \%$, while homogeneity of the Group 2 was $68.8 \%$. Thus, it can be said that Group 1 was more homogeneous than Group 2.

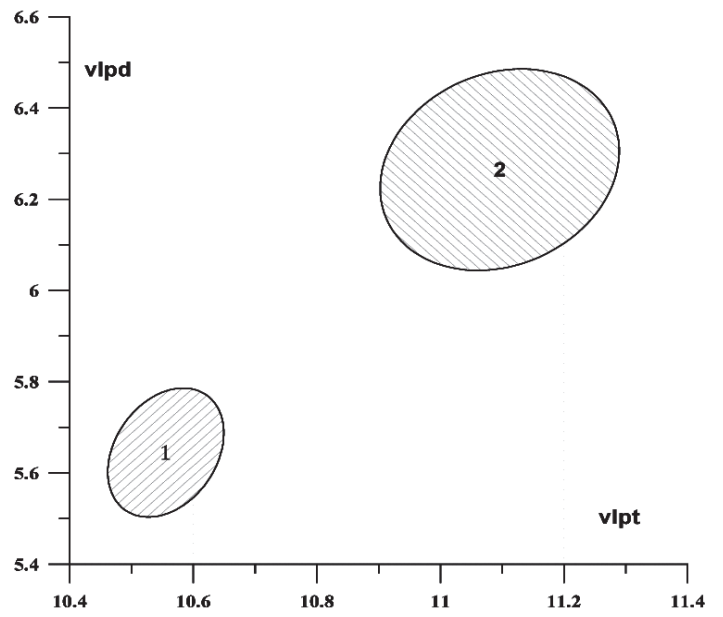

Graph 1. Ellipses (trust interval) of the groups of respondents in tests $M$ type of carrying the ball (vdlp) and carrying the ball with a pass (vdlpd)
The results of the M type of carrying the ball vdlp and of the carrying the ball with a pass- vdlpd were presented on the abscise (horizontal axis) and ordinate (vertical axis) respectively (Graph 1 ). It can be observed that compared to the "M type of carrying the ball" (vdlp), the Group 1 has lowest value of the speed evaluation of carrying the ball i.e. the best result at the test, and the highest value is by the Group 2 i.e., the worst result at the test. Compared to the test of carrying the ball with passing (vdlpd), Group 1 has lowest value of the assessment of the speed of carrying the ball i.e., the best result while the highest value at this test is achieved by the Group 2 and consequently the worst result. As the results of the speed evaluation tests of carrying the ball are expressed in seconds it means that numerically highest result is the worst one while the numerically lowest is the best one.

The procedure of the analysis of the group profiles was done based on the results of the repeated measures of $M$ type of carrying the ball (vdlp1, vdlp2, vdlp3) and carrying the ball with a pass vdlpd (vdlpd1, vdlpd2, vdlpd3) between the groups of respondents.

Table 4. Significance of difference between the profiles of the groups of respondents with regard to the results of repeated measurements in the tests vdlp and vdlpd

\begin{tabular}{lcccccc}
\hline & \multicolumn{2}{c}{$\mathbf{v d l p}$} & & \multicolumn{2}{c}{ vdlpd } \\
\cline { 2 - 3 } \cline { 5 - 7 } & $\mathbf{F}$ & $\mathbf{p}$ & & $\mathbf{F}$ & \multicolumn{1}{c}{$\mathbf{p}$} \\
\hline MANOVA & 163.887 & .0000 & & 17.3672 & .0000 \\
Parallelness & 5.45 & .0052 & & 5.4571 & .0052 \\
Direction of growth & 32.90 & .0000 & & 35.4381 & .0000 \\
Equal results & 4.20 & .0187 & & 18.6746 & .0000 \\
\hline
\end{tabular}

By multivariance analysis of variance it was established that there are significant differences between the two groups of respondents, $\mathrm{p}=.000$ (Table 4). The analysis of parallelness established that the profile of the two groups of the respondents are not parallel (pп $=.005$ ) while the analysis of the equal results established that there is difference between some results of the two groups of respondents, $\mathrm{p}=.019 ; .000$ (Table 4 ).

\section{DISCUSSION}

Carrying the ball is technical ability that takes important place in the structure of the game of soccer.
The application of this technical element depends on the playing position, tactical tasks and the level of technical abilities of the soccer players. Different results were achieved when it comes to the assessment of the time during which a player carries the ball. The analyses show that the player, during the game, while carrying the ball, covers the distance between $119-286$ meters or $1.2-2.4 \%$ of the overall covered distance (Di Salvo et al., 2007). Jukić and Milanović (2007) in their research concluded that in the course of one match a player covers with the ball at his feet $0.5-3 \%$ of the overall covered distance and that the possession of the ball per player is from 0.3 to 3.1 minutes. The greatest number of the ball car- 
rying are realized by defensive linkmen (11.78) who through greater number of ball touching try to find the most efficient solution in the game (Janković, \& Leontijević, 2008).

Taking into account the importance of this technical element, the speed of carrying the ball was evaluated by two tests: the „M type of carrying the ball and the test of carrying the ball with a pass". By the analysis of the achieved results it was established that there is a difference between the respondents from the groups with regard to the results of the speed evaluation of carrying the ball in the tests of $M$ type of carrying the ball $(\mathrm{p}=.000)$ as well as in the test of carrying the ball with a pass " $(\mathrm{p}=.000)$.

Based on the analysis of the results of the tests for assessment of the speed of the ball carrying in the respondents it can be said that Group 1 realized statistically significantly better results at the test of ball carrying with a pass and at the test of $M$ type of carrying the ball. Contrary to Group 1 the respondents from the Group 2 scored statistically significantly worse results in both speed evaluation tests of ball carrying. Based on the results of this research it can be said that both applied tests are sensitive compared to the set criterion and therefore they clearly distinguish players according to the qualitative level of their successfulness in the game of soccer. Also, carrying the ball in combination with the ball control is an element of soccer technique which significantly affects the efficiency of individual performance in technical and tactical requests of the game. If we consider the data showing that carrying the ball is extremely rarely deployed in competitive activities (Janković, \& Leontijević, 2008; 2009), it can be concluded for the moment that carrying is not essentially important element of soccer technique. However, through the tasks of ball carrying set in this research a soccer player shows also specific abilities such as sense of the ball, ball kicks and ball receiving (test - vdlpd), agility. Thus, it can be assumed that based on the results of this research, the Group 1 examinees are more successful in the competitive activities, thanks to, among other things, quality and efficiency manifested in the testing abilities (carrying the ball - vdlp, vdlpd).

High values of homogeneity of the results in these two groups of respondents (Group 1 homogeneity 1 $75 \%$, and Group $22-68.75 \%$ ) lead to the conclusion that this ability is essential quality of young soccer players. The discrimination coefficient of 0.269 for the results of $M$ type of carrying the ball and 0.197 for the results of carrying the ball with a pass indicate that the results of these two tests can lead to qualitative distinction of young soccer players. Therefore, the applied tests in this research can be recommended as a means for identifying promising soccer players for whom it can be anticipated that they will reach high level of competitive efficiency later on in their development. Similar results were obtained by other researchers involved in these types of research (Williams, \& Reilly, 2000). Some of the conducted investigations proved that carrying the ball, i.e., some tests of carrying the ball proved the highest level of distinction between young elite and amateur soccer players. (Reilly, Bangsbo, \& Franks, 2000a; Reilly, Williams, Nevill, \& Franks, 2000b). Additionally, some studies show that the ball carrying is the most selective technical ability of soccer players (Vaeyens et al. 2006).

Based on the results of this research, together with the conclusions from the studies that directly or indirectly dealt with prediction and selection of young soccer players, it is particularly important to underline the importance of carrying and controlling the ball in the overall technical preparation of the youngest soccer trainees. It is through the contents of activities, dominated by this activity of players with the ball, that soccer players develop integrally soccer-specific abilities which positively transfer to later application of competitive forms of soccer technique manifestation. All that has been said in the above text is especially accentuated when it comes to the fact that initial selection is lowered to the age of 5 years.

\section{CONCLUSION}

In line with the obtained results it can be concluded that carrying the ball as technical element, has significant influence on the quality of soccer players' performance. Although the tendency of modern soccer play is to quickly release the ball, more precise passes and fast change of movement direction, fast carrying the ball cannot be underestimated. The players who show small variation of the running speed with or without the ball have greater advantage in resolving the situations "one on one", efficient invasion of the space with the ball as well as the resolution of the situations „under pressure" by the opponents. Such features are characteristic for exceptionally talented soccer players and primarily of the technically trained individuals. Therefore, the results of the research confirmed the 
presumption that success in soccer is directly linked to the level of technical abilities, in this case directly to the technique of the ball carrying. Development

\section{REFERENCES}

1. Abbott, A., Button, C., Pepping, G., \& Collins, D. (2005). Unnatural Selection: talent identification and development in sport. Nonlinear dynamics, psychology and life Sciences, 9(1), 61-88.

2. Aleksić, V., \& Janković, A. (2006). FUDBAL: Istorija-Teorija-Metodika [Soccer: History-Theory-Methodic. In Serbian] Beograd: Fakultet sporta i fizičkog vaspitanja.

3. Bangsbo, J. (2003). Fitness training in soccer: A scientific approach. Spring City: Reedswain.

4. Bompa, O.T. (2000). Cjelokupan trening za mlade pobjednike. Zagreb: Gopal.

5. Di Salvo, V., Baron, R., Tschan, H., Calderon Montero, F.J., \& Pigozzi, F. (2007). Motion Characteristics in Elite Level Soccer. International Journal of Sports Medicine, 28(3), 222-227.

6. Grant, A.G., Williams, A.M., \& Reilly, T. (1999) Analysis of the goals scored in the 1998 World Cup. Journal of Sports Sciences 17, 826-827.

7. Hoff, J., Wisloff, U., Engen, L., Kemi, O., \& Helgerud, J. (2002). Soccer specific aerobic endurance training, British Journal of Sports Medicine, 36, 218-221.

8. Janković, A., \& Leontijević, B. (2008). Struktura tehničko takmičarske aktivnosti u savremenom fudbalu [The structure of technical and competitive activities in modern soccer. In Serbian]. Fizička kultura, 62(1-2) 159-169.

9. Janković, A., \& Leontijević, B. (2009). Analiza primene pojedinih tehničkih elemenata u fudbalu $\mathrm{u}$ zavisnosti od pozicije igrača u timu [Analysis of application of certain technical elements in soccer depending on the positions of the players on the team. In Serbian]. Fizička kultura, 63(1), 76-88.

10. Jukić, I., Milanović, D., Marković, G., Milanović, L., Šimek, S., \& Gregov, C. (2007). Scientific and practical approach to physical conditioning of athletes. Serbian Journal of Sports Sciences, 1 (4), 116-112. and improvement of this technical element is one of the main aims of the training of young soccer players which is supported by the results of this research.

11. Malina, R.M., Cumming, S.P., Kontos, A.P., Eisenmann, J.C., Ribeiro, B., \& Aroso, J. (2005). Maturity-associated variation in sport-specific skills of youth soccer players aged 13-15 years. Journal of Sports Sciences, 23(5), 515-522.

12. Radosav, R., Molnar, S., i Smajić, M. (2003). Teorija i metodika fudbala [Theory and methodic of soccer. In Serbian]. Novi Sad: Fakultet fizičke kulture.

13. Reilly, T., Bangsbo, J., \& Franks, A. (2000a): Antropometric and physiological predispositions for elite soccer, Journal of Sports Sciences, 18, 669683.

14. Reilly, T,, Williams, A.M., Nevill, A. \& Franks, A. (2000b). A multidisciplinary approach to talent identification in soccer. Journal of Sport Sciences, 18 (9), 695-702.

15. Rosch, D., Hodgson, R., Peterson, L., Graf-Baumann, T., Junge, A., Chomiak, J., \& Dvorak J. (2000). Assessment and evaluation of football performance. American Journal of Sports Medicine, 28, 29-39.

16. Vaeyens, R., Malina, R.M., Janssens, M., Van Renterghem, B., Bourgois, J., Vrijens, J., \& Philippaerts, R.M. (2006). A multidisciplinary selection model for youth soccer: the Ghent Youth Soccer Project. British Journal of Sports Medicine, 40, 928-934.

17. Williams, M., \& Reilly, T. (2000). Talent identification and development in soccer. Liverpool: John Moores University.

18. Zubillga, A., \& Gorospe, G. (2007). Match analysis of 2005-06 Champions League Final with Amisco system. In Reilly and Korkusuz. Science and football VI: the proceedings of the Sixth World Congress on Science and Football (pp. 267-272). London: Routledge. 


\title{
EMPFINDLICHKEIT VON TESTS FÜR DIE EINSCHÄTZUNG DER GESCHWINDIGKEIT DER BALLFÜHRUNG BEI FUßBALLSPIELERN IM JUGENDALTER
}

\begin{abstract}
Zusammenfassung:
Ziel der Untersuchung war die Erkundung der Testempfindlichkeit für die Einschätzung der Geschwindigkeit der Ballführung. An der Untersuchung nahmen 76 Prüflinge männlichen Geschlechts im Alter von 17 Jahren teil ( \pm 6 Monate), die in zwei, im qualitativen Sinne unterschiedliche Untergruppen eingeteilt wurden. Für die Feststellung der Geschwindigkeit der Ballführung wurden Tests der Ballführung durch Kegel hindurch („M“-Ballführung) und der Ballführung durch Slalom mit Ballabgabe und -annahme durchgeführt. Anhand der gewonnenen Ergebnisse wurde festgestellt, dass Prüflinge aus der aus erfolgreicheren Fußballspielern bestehenden Gruppe (Gruppe 1) bei den angewendeten Tests bessere Ergebnisse erzielten als Prüflinge aus der Gruppe, die aus Fußballspielern zusammengesetzt war, die für schlechter rangierte Teams spielen und keine Mitglieder von repräsentativen Mannschaften sind (Gruppe 2). Hohe Werte der Ergebnishomogenität bei diesen beiden Gruppen der Prüflinge (Homogenität der Gruppe 1 beträgt 75\%, der Gruppe 2 68,75\%) weisen auf die Schlussfolgerung hin, dass diese Fertigkeit eine wichtige Charakteristik junger Fußballspieler darstellt. Der Diskriminierungskoeffizient von 0,269 für Ergebnisse des „M“-Tests für Ballführung und 0,197 für Ergebnisse des Tests der Ballführung mit Ballabgabe und -annahme weisen darauf hin, dass durch die Ergebnisse dieser beiden Tests im qualitativen Sinne junge Fußballspieler unterschieden werden können. In Einklang mit den gewonnenen Ergebnissen kann festgestellt werden, dass Ballführung als technisches Element einen bedeutenden Einfluss auf die Qualität des Spiels der Fußballspieler ausübt.
\end{abstract}

Schlüsselwörter: FUßBALL / TECHNIK / BALLFÜHRUNG / GESCHWINDIGKEIT / JUGENDLICHE

Received: 11.04.2016.

Accepted: 02.11.2016.

(c) 2016 The Author. Published by Physical Culture (www.fizickakultura.com). This article is an open access article distributed under the terms and conditions of the Creative Commons Attribution license (http://creativecommons. org/licenses/by/3.0/rs/).

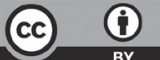




\title{
ОСЈЕТЉИВОСТ ТЕСТОВА ЗА ПРОЦЈЕНУ БРЗИНЕ ВОЪЕЊА ЛОПТЕ КОД ФУДБАЛЕРА ОМЛАДИНСКОГ УЗРАСТА
}

\author{
Бојан Ракојевић, Бојан Леонтијевић, Александар Јанковић \\ Факултет спорта и физичког васпитања, Универзитет у Београду
}

\begin{abstract}
Сажетак
Циљ истраживања је био да се изврши испитивање осетљивости тестова за процјену брзине вођења лопте. У истраживању је учествовало 76 испитаника мушког пола, старости 17 година ( \pm 6 мјесеци), који су били подијељени у двије квалитативно различите подгрупе. За утврђивање брзине вођења лопте изведени су тестови вођења лопте између купа („М“ вођење лопте) и слалом вођења лопте са додавањем. Добијеним резултатима је утврђено да су испитаници из групе коју су сачињавали успјешнији фудбалери (група 1) остварили боље резултате на примијењеним тестовима у поређењу са оствареним резултатима испитаника из групе коју су сачињавали фудбалери који наступају за слабије рангиране екипе и који нису чланови репрезентативних селекција (група 2). Високе вриједности хомогености резултата код ове двије групе испитаника (хомогеност групе 1 је 75\%, а групе $268.75 \%$ ) упућују на закључак да је ова способност битна карактеристика младих фудбалера. Коефициент дискриминације од 0.269 за резултате теста „М“ вођење лопте и 0.197 за резултате теста вођење лопте са додавањем, указују да се резултатима са ова два теста могу квалитативно разликовати млади фудбалери. Сагласно добијеним резултатима може се констатовати да вођење лопте као технички елемент има значајан утицај на квалитет играња фудбалера.
\end{abstract}

Кључне ријечи: ФУДБАЛ / ТЕХНИКА / ВОЂЕЊЕ ЛОПТЕ / БРЗИНА / ОМЛАДИНЦИ

\section{УВОД}

Техничке способности фудбалера имају битну улогу у процесу идентификације и селекције играча, планирању тренажног процеса, одређивању тактичке формације, постављању циљева тренинга и такмичења (Abbott, Button, Pepping, \& Collins, 2005; Bompa, 2000). Као што је већ peчено, то су есенцијалне фудбалске вјештине без чијег усавршавања је ограничено испољавање морфолошких, моторичких и функционалних потенцијала фудбалера (Алексић, \& Јанковић, 2006). Како је период адолесценције погодан за усвајање нових знања и вјештина, тако је, у исто вријеме, и изузетно нестабилан, јер под утицајем раста и развоја неријетко долази до нарушавања координације и губљења неких до тада стечених вјештина. Из тога разлога је усавршавање технике примаран задатак током цијелог тенажног процеса младих играча. Готово све водеће фуд- ठалске школе главни акценат у својим тренажним програмима стављају на развој брзине и технике као главних способности на којима се базира процес селекције играча, како за улогу у тиму, тако и за одређивање нивоа играња. Ајаксова школа фудбала, као једна од најпризнатијих свјетских школа, у процесу обучавања се руководи „TIPS“ (technique, intelligence, personality, speed) принципом, гдје се поред карактера личности и интелигенције играња посебна пажња посвећује развоју технике и брзине (Bangsbo, 2003).

Вођење лопте је елемент фудбалске технике који се примјењује када играч не налази задовољавајуће решење за одигравање лопте, када је износи из казненог простора, када жели да прикрије своју намјеру прије одигравања лопте, када креће у варање, када претрчава противника по завршеном варању (Радосав, Молнар, \& Смајић, 2003). У току утакмице, активно вријеме једног играча са лоптом износи свега неколико минута. Највећи

164 Кореспонденција са: Александар Јанковић, Факултет спорта и физичког васпитања Београд, Благоја Паровића 156, 11030 Београд; e-mail:aleksandar.jankovic@sfv.bg.ac.rs 
дио овога времена отпада на вођења лопте која могу да буду праволинијска и криволинијска. Анализом техничке активности фудбалера током утакмице уочено је да боље екипе мање времена проведу у вођењу лопте што може да се објасни бољом тактичком поставком игре, ефикаснијим кретањем играча без лопте и бољим прегледом игре (Hoff, Wisloff, Engen, Kemi, \& Helgerud, 2002). Играч у току утакмице водећи лопту пређе дистанцу између 119-286 метара или 1,2-2,4\% укупно пређене дистанце (Di Salvo, Baron, Tschan, Calderon Montero, \& Pigozzi, 2007). Током једне утакмице играч пређе „са лоптом у ногама“ $0,5-$ $3 \%$ укупно пређене дистанце, док посјед лопте по играчу износи од 0,3 до 3,1 минута (Jukić et al., 2007). Анализом фудбалских утакмица уочава се да позиција играња и тактички задаци одређују учесталост испољавања појединих техничких елемената. Фудбалери који имају способност брзог вођења лопте се намећу као играчи средине терена или бочни играчи. Највећи број вођења лопте остварују дефанзивни везни играчи $(11,78)$ који кроз већи број додира лопте покушавају да нађу најефикасније решење у игри док најмањи број вођења лопте остварују централни одбрамठени играчи (Јанковић, \& Леонтијевић, 2009). Наведена истраживања се односе на сениорске тимове, док се веома мали број истраживача бавио оваквим типом анализа утакмица код млађих категорија фудбалера. Екипе током утакмица претрче приближно исту дистанцу при сличној средњој брзини трчања, док се значајније разлике уочавају у квантитету и квалитету употребе техничких елемената. Истраживањима се дошло до закључака да побједничке екипе остварују знатно више удараца по лопти што довољно говори о важности техничких елемената и њиховом мјесту у игри (Grant, Williams, \& Reilly, 1999; Zubillaga, \& Gorospe, 2007).

Проблем истраживања је одређивање нивоа значајности техничких способности у контексту њиховог утицаја на квалитет играња фудбалских екипа. Кључни проблем, као и цјелокупна проблемска орјентација овог истраживања, везује се за испитивање осетљивости тестова за процјену брзине вођења лопте (вођење лопте између купа и вођење лопте са додавањем). Очекује се да резултати истраживања допринесу решавању проблема који се тиче значаја и утицаја техничких способности на квалитет играња фудбалера омла- динског узраста, као и повећању ефикасности тренажних програма у дијелу који се тиче развоја технике фудбалера. Такође, добијени резултати треба да дају одговор на питање које су то техничке вјештине које праве највећу квалитативну разлику између фудбалера различито пласираних екипа.

Циљ рада је био утврђивање техничких способности у контексту разликовања успјешних од мање успјешних фудбалера и испитивање остљивости специфичних тестова вођења лопте у фудбалу.

\section{МЕТОД}

\section{Узорак испитаника}

Истраживањем је обухваћено 76 испитаника, који су били подијељени у двије групе од по 44 испитаника (група 1) и 32 испитаника (група 2), мушког пола, старости 17 година ( \pm 6 мјесеци) који су укључени у фудбалски тренажни процес најмање три године. Први група је била састављена од фудбалера успјешнијих екипа док је друга састављена од фудбалера мање успјешних екипа. Критеријум успјешности узет је на основу пласмана екипа у текућем првенству, броју репрезентативних играча који наступају за омладинску или младу селекцију, традиција омладинских школа и успјешности сениорских тимова ових екипа.

\section{Узорак варијабли}

Узорак варијабли су чиниле варијабле из простора моторичких способности фудбалера, реализованих примјеном два различита теста за процјену специфичне фудбалске брзине вођења лопте. За утврђивање брзине вођења лопте примењени су тестови вођења лопте између купа („М“ вођење лопте) и слалом вођења лопте са додавањем. Поузданост ових тестова је потврђена у неколико референтних радова из области фудбала (Rosch et al., 2000; Malina et al., 2005).

У циљу испитивања утицаја специфичних фудбалских тестова на варијабле брзине, дефинисане су двије варијабле:

- „М“ вођење лопте између купа (вђлп), (изражено у секундама),

- слалом вођење лопте са додавањем (вђлпд) (изражено у секундама). 


\section{Протокол мјерења}

Сви тестови су изведени на фудбалским теренима са синтетичком подлогом и испитаници су све тестове изводили у фудбалској обући. Сви тестови су извођени са фудбалском лоптом стандардне величине (број 5). За потребе овог истраживања користиле су се фото ћелије најновије генерације (Smart speed system, Аустралија) помоћу којих се утврђивало вријеме потребно за извођење тестова вођења лопте.

Тесй слалом вођеґе лоййе са додавањем се изводио тако што је испитаник најбрже могуће водио лопу између 4 купе, након чега је шутирао лопту у правцу клупе тако да се одбије како би поново наставио вођење у правцу циља. Стартна линија је била уједно и циљна. Све купе су постваљене у линији, тако да је прва купа постављена на стартној линији, а следеће три на растојању од по 2,25 м. Клупа ширине 1,2 м се налазила на 9 метара од стартне линије.

Тесй „M“ вођеньа лойте се изводио у квадрату димензија $9 \times 9$ м, тако да су четири купе постављене у угловима квадрата, а пета купа је постављена на 4,5 м између прве и последње купе. Овако постављене купе су биле у облику слова „М“, које је уједно и представљало путању вођења лопте. Циљ оба теста је био да се за што краће вријеме изведе задати тест.

Прије почетка тестирања сви испитаници су изводили 15-минутно загријавање како би се избјегла евентуална истегнућа мишића и друге повреде које су могле настати приликом извођења кретних задатака. Након завршеног 15-минутног загријавања, испитаници су изводили задате тестове са циљем упознавања са тестовима, у трајању од 10 минута, средњом брзином извођења. У истраживању су поред испитаника, учествовала два мјериоца, који су контролисали извођење тестова и биљежили остварене резултате. Током главног тестирања сваки испитаник је кретни задатак извео по три пута.

\section{Обрада података}

Обрада резултата је вршена применом мултиваријантне анализе (МАНОВА) и дискриминативне анализе као и дескриптивних параметара, средње вриједности (М), стандардне девијације (СД), минималних и максималних вриједности, коефицијента варијације (Цв), интервала повјерења, те мјера асиметрије (Скјунис-СК) и мјера спљоштености (Куртозис-КУ). Од униваријантних поступака примијењени су АНОВА, т-тест и Роу-ев тест. Сви статистички тестови су били обрађени коришћењем SPSS 17.0 програма (SPSS INC Chicago, IL)

\section{РЕЗУЛТАТИ}

Централни и дисперзиони параметри, мјере асиметрије и спљоштености код процјене вођења лопте испитаника репрезентују групе и усмјеравају на могућност примјене параметријских поступака.

Таסела 1. Централни и дисперзиони параметри и мјере асиметрије и спљоштености процјене брзине вођења лопте испитаника групе 1

\begin{tabular}{|c|c|c|c|c|c|c|c|c|c|c|c|}
\hline & M & СД & Ep & Мин & Макс & KB & & & CK & КУ & p \\
\hline вђлп & 10.56 & .31 & .05 & 9.9 & 11.2 & 2.96 & 10.46 & 10.65 & -.07 & -.50 & .890 \\
\hline вђлпд & 5.64 & .47 & .07 & 5.0 & 6.9 & 8.34 & 5.50 & 5.79 & .60 & -.22 & .798 \\
\hline
\end{tabular}

(Легенда: вђлп - „М” вођење лопте између купа; вђлпд - слалом вођење лопте са додавањем; М - средња вредност; СД - стандардна девијација; Ер - стандардна грешка; Мин - минимална вредност; Макс - максимална вредност; КВ - коефицијент варијације; ИП - интервал повезаности; Ск - скјунис; КУ - куртозис)

Посматрајући резултате тестирања прве групе, може се видети да минималне (мин) и максималне (макс) вриједности резултата процјене вођења лопте указују да се вриједности налазе у очекиваном распону (табела 1). Вриједности коефицијента варијације (КВ) указују на хомогеност резултата испитаника групе 1 , за оба примјењена теста (вђлп = 2.96 и вђлпд = 8.34). Резултати су даље позали да је расподјела резултата негативно асиметрична што значи да крива расподјеле резултата нагиње ка већим вриједностима, односно да има више лошијих резултата у односу на нормалну расподјелу код теста вођење лопте са додавањем (вђлпд - .60). Са друге стране, код теста 
„M“ вођења лопте (вђлп) расподјела резултата позитивно је асиметрична што значи да крива расподјеле резултата нагиње ка мањим вриједностима, односно да има више бољих резултата у односу на нормалну расподјелу (.07). Негативне вриједности Куртозиса (ку) указују да је крива спљоштена код два теста за процјену брзине вођења лопте (вђлп = -.50; вђлпд = -.22). Дистрибуција вриједности углавном се креће у оквиру нормалне расподјеле (п) код теста „М“ вођење лопте $($ вђлп $=.89)$ и код теста слалом вођење лопте са додавањем (вђлпд $=.80)$.

Табела 2. Централни и дисперзиони параметри и мјере асиметрије и спљоштености процјене вођења лопте испитаника групе 2

\begin{tabular}{lccccccccccc}
\hline & М & СД & Ер & Мин & Макс & КВ & \multicolumn{2}{c}{ ИП } & СК & КУ & р \\
\hline вђлП & 11.10 & .55 & .10 & 10.1 & 12.1 & 4.92 & 10.90 & 11.29 & .02 & -.82 & .977 \\
вђЛПд & 6.26 & .62 & .11 & 5.1 & 7.4 & 9.94 & 6.04 & 6.49 & -.05 & -.79 & .993 \\
\hline
\end{tabular}

(Легенда: вђлп - „М” вођење лопте између купа; вђлпд - слалом вођење лопте са додавањем; М - средња вредност; СД - стандардна девијација; Ер - стандардна грешка; Мин - минимална вредност; Макс - максимална вредност; КВ - коефицијент варијације; ИП - интервал повезаности; Ск - скјунис; КУ - куртозис)

Минималне (мин) и максималне (макс) вриједности резултата са теста за процјену вођења лопте испитаника групе 2 указују да се вриједности налазе у очекиваном распону (табела 2). Вриједности коефицијента варијације (к.вар) указују на хомогеност резултата испитаника групе 2 код тестова „М“ вођења лопте (вђлп) (4.92) и слалом вођења лопте са додавањем (вђлпд) (9.94). Смањене вредности Скјуниса (ск) указују да је расподјела позитивно асиметрична, што значи да крива расподјеле резултата нагиње ка мањим вриједностима, односно да има више бољих резултата у односу на нормалну расподјелу, код теста вођења лопте са додавањем (вђлпд) (-.05). Вриједности Скјуниса (ск) указују да расподјела није асиметрична код теста „М“ вођења лопте (вђлп) (.02). Негативне вриједности Куртозиса (ку) указују да је крива спљоштена, код два теста за процјену брзине вођења лопте (вђлп = -.82; вђлпд $=-.79)$. Дистрибуција вриједности резултата углавном се креће у оквиру нормалне расподјеле (п) код два теста за процјену брзине вођења лопте (вђлп = .98; вђлпд = .99).

Мултиваријантном анализом добијених резултата закључује се да постоји статистики значајна разлика између двије групе испитаника (п=.000). Дискриминативном анализом за синтетизоване резултате са два теста процјене брзине вођења лопте, закључује се да постоји значајна разлика и јасно дефинисана граница између група испитаника у односу на резултате теста процјене брзине вођења лопте за тестове „М“ вођење лопте (вђлп) и вођење лопте са додавањем ( $\mathrm{p}=.000)$.

Коефицијенат дискриминације указује да је највећи допринос дискриминацији између група испитаника, у односу на резултате са тестова за процјену брзине вођења лопте код теста „М“ вођења лопте 269 (вђлп) док је исти коефицијент за тест вођење лопте са додавањем .197 (вђлпд).

Табела 3. Карактеристике група испитаника у односу на резултате тестова за процјену брзине вођења лопте (* - значајно веће, ${ }^{1}$ број од колико модалитета група је веће)

\begin{tabular}{lccr}
\hline & група 1 & група 2 & к.диск. \\
„М“ вођење лопте & мање & веће & 57.725 \\
вођење лопте са додавањем & мање & веће $^{* 1}$ & 42.275 \\
\hline
\end{tabular}

На основу анализе резултата са тестова за процјену брзине вођења лопте испитаника може се рећи да:

- резултати групе 1 са теста „М“ вођење лопте (вђлп) и теста вођење лопте са додавањем (вђлпд) указују да ова група има својства мањих вриједности остварених резултата, што значи да су карактеристике ове групе бољи резултати,

- резултати групе 2 са теста „М“ вођење лопте (вђлп) и теста вођење лопте са додавањем (вђлпд) указују да ова група има својства већих $\left(\right.$ већ $\left.^{* 1}\right)$ вриједности остварених резултата, што 
значи да су каракетристике ове групе лошији резултати.

Резултати су показали и да дефинисане карактеристике групе 1 има 33 од 44 испитаника који су припадали овој групи, што указује на хомогеност од 75.0\%, док је хомогеност групе 2 била $68.8 \%$, према томе, може се рећи да је група 1 била хомогенија од групе 2.

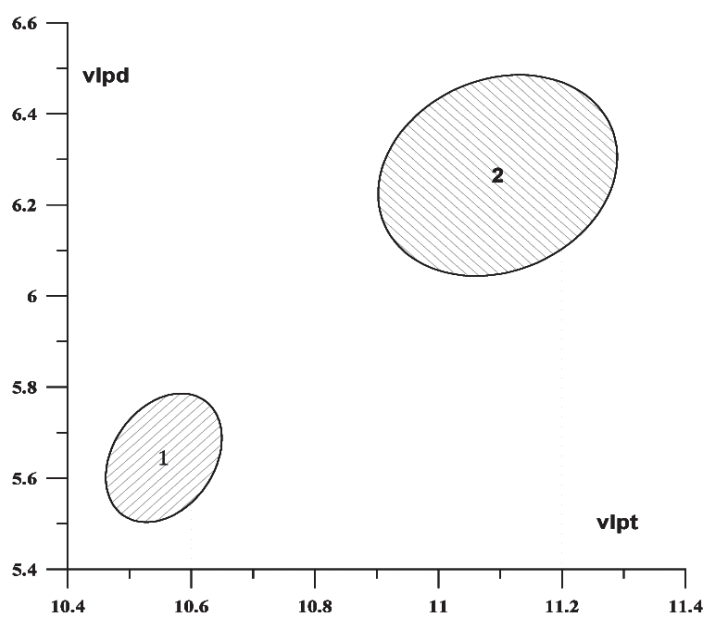

Графикон 1. Елипсе (интервали поверења), група испитаника код тестова „М” вођење лопте (вђлп) и вођење лопте са додавањем (вђлпд)
На апсциси (хоризонтална оса) су представљени резултати са теста „М“ вођења лопте - вђлп, а на ординати (вертикална оса) су представљени резултати са теста вођења лопте са додавањем вђлпд (графикон 1). Могуће је запазити да у односу на тест „М” вођења лопте (вђлп), група 1 има најмању вриједност процјене брзине вођења лопте односно најбољи резултат на тесту, а највећу вредност група 2, односно најлошији резултат на тесту. У односу на тест вођења лопте са додавањем (вђлпд), група 1 има најмању вриједност процјене брзине вођења лопте, односно најбољи резултат, док највећу вриједност на овоме тесту има група 2, односно најлошији резултат. Како се резултати тестова за процјену брзине вођења лопте изражавају у секундама, тако је нумерички највећи резултат најлошији, а нумерички најмањи је најбољи.

Поступак анализе профила група реализован је на основу резултата поновљених мјерења „М” вођења лопте (вђлп1, вђлп2, вђлп3) и вођења лопте са додавањем - вђлпд (вђлпд1, вђлпд2, вђлпд3) између група испитаника.

Табела 4. Значајност разлике профила између група испитаника у односу на резултате поновљених мјерења на тестовима вђлп и вђлпд

\begin{tabular}{lccccc}
\hline & \multicolumn{2}{c}{ вђлп } & & \multicolumn{2}{c}{ вђлпд } \\
\cline { 2 - 3 } \cline { 5 - 6 } & $\mathbf{F}$ & $\mathbf{p}$ & & $\mathbf{F}$ & $\mathbf{p}$ \\
\hline МАНОВА & 163.887 & .000 & & 17.3672 & .000 \\
паралелност & 5.45 & .005 & & 5.4571 & .005 \\
правац раста & 32.90 & .000 & & 35.4381 & .000 \\
једнаки резултати & 4.20 & .018 & & 18.6746 & .000 \\
\hline
\end{tabular}

Мултиваријантном анализом варијансе установљено је да постоје значајне разлике између резултата двије групе испитаника, $\mathrm{p}=.000$ (табела 4). Анализом паралелности установљено је да профили двије групе испитаника нијесу паралелни $(\mathrm{p}=.005)$, док је анализом једнаких резултата установљено да постоји разлика између неких резултата код двије групе испитаника, $\mathrm{p}=.019 ; .000$ (табела 4).

\section{ДискУСИЈА}

Вођење лопте је техничка способност која заузима важно мјесто у структури фудбалске игре.
Примјена овога техничког елемента зависи од позиције играња, тактичких задатака и од нивоа техничких способности фудбалера. Истраживачи су дошли до различитих резултата када је у питању процјена времена које фудбалер "потроши" у вођењу лопте. Анализе показују да фудбалер у току утакмице водећи лопту пређе дистанцу између 119-286 метара или 1,2-2,4\% укупно пређене дистанце (Di Salvo et al., 2007). Истраживањем Јукића и сарадника (Jukić et al., 2007) закључено је да током једне утакмице играч пређе са лоптом у ногама 0,5-3\% укупно пређене дистанце а да посјед лопте по играчу износи од 0,3 до 3,1 минута. Највећи број вођења лопте остварују дефанзивни везни играчи $(11,78)$ који кроз већи број додира 
лопте покушавају да нађу најефикасније решење у игри (Јанковић, \& Леонтијевић, 2008).

Узимајући у обзир важност овога техничког елемента, брзина вођења лопте процјењивана је помоћу два теста и то теста „М“ вођење лопте и теста „вођење лопте са додавањем“. Анализом остварених резултата утврђена је разлика између група испитанка у односу на резултате процјене брзине вођења лопте код теста „М“ вођење лопте $(\mathrm{p}=.000)$ као и код теста „вођење лопте са додавањем“ $(\mathrm{p}=.000)$.

На основу анализе резултата са тестова за процјену брзине вођења лопте испитаника може се рећи да је група 1. остварила статистички значајно боље резултате на тесту вођења лопте са додавањем и на тесту „М“ вођење лопте. За разлику од групе 1 , испитаници групе 2 . су остварили статистички значајно лоше резултате код оба теста за процјену брзине вођења лопте. На основу резултата овог истраживања може се рећи да су оба примјењена теста осетљива у односу на постављени критеријум, па према томе јасно диференцирају фудбалере према квалитативном нивоу њихове успјешности у фудбалском спорту. Такође, вођење лопте, уз комбинацију са контролом лопте, представља елемент технике фудбала који значајно утиче на ефикасност индивидуалног испољавања у техничко-тактичким захтјевима игре. Ако се осврнемо на податак према којем се вођење лопте изразито ријетко користи у такмичарској активности (Јанковић, и Леонтијевић, 2008; Јанковић, и Леонтијевић, 2009), може се, на први поглед, извући закључак да вођење и није суштински битан елемент технике фудбала. Међутим, кроз задате тестове вођења лопте, примјењене у овом истраживању, фудбалер показује и специфичне способности као што су: осјећај за лопту, ударце по лопти и примања лопте (тест вђлпд), агилност, окретност. Узимајући све у обзир може се рећи да фудбалер, реализацијом ових тестова, демонстрира индивидуални ниво специфичне фудбалске координације и осјећај за лопту. Па према томе, може се констатовати да су, на основу резултата овог истраживања, испитаници групе 1 усјпешнији у такмичарској активности, између осталог, и због квалитета и ефикасности које испољавају у тестираним способностима (вођење лопте - вђлп, вђлпд)

Високе вриједности хомогености резултата код ове двије групе испитаника (хомогеност групе 1 - 75\%, а групе 2 - 68.75\%) упућују на закључак да је ова способност битна карактеристика младих фудбалера. Коефицијент дискриминације од 0.269 за резултате теста „М“ вођење лопте и 0.197 за резултате теста вођење лопте са додавањем, указују да се резултатима са ова два теста могу квалитативно разликовати млади фудбалери. Према томе, примјењени тестови у овом истраживању могу се препоручити као средство идентификације будућих фудбалера за које се може претпоставити да ће достићи висок ниво такмичарске ефикасности у каснијим периодима развоја. Сличне резултате добили су и остали истраживачи који су се бавили овим проблемом истраживања (Williams, \& Reilly, 2000). У једном броју истраживања констатовано је да је вођење лопте, односно поједини тестови вођења, показало највећи степен дискриминативности између младих елитних и аматерских фудбалера (Reilly, Bangsbo, \& Franks, 2000a; Reilly, Williams, Nevill, \& Franks, 2000b). Такође, поједине студије, својим истраживањем, показују да је вођење лопте најдискриминативнија техничка способност фудбалеpa (Vaeyens et al., 2006).

На основу резултата овог истраживања, али и закључака студија које су се на директан или индиректан начин бавиле предикцијом и селекцијом младих фудбалера, потребно је посебно нагласити важност вођења и контроле лопте у свеукупној техничкој припреми најмлађих фудбалских полазника. Управо кроз тренажне садржаје рада, у којима доминира ова активност играча са лоптом, на интегралан начин развијају се специфичне способности фудбалера које имају позитиван трансфер на каснију примену такмичарских форми испољавања технике фудбала. Све претходно речено, посебно долази до изражаја ако се узме у обзир чињеница да је почетна селекција спуштена на узраст од 5 година старости.

\section{ЗАКЉУЧАК}

Сагласно добијеним резултатима може се констатовати да вођење лопте као технички елемент, има значајан утицај на квалитет играња фудбалеpa. Иако је тенденција савремене фудбалске игре брзо ослобађање од лопте, прецизни пасови и брза промјена смјера кретања, важност брзог вођења лопте се никако не може занемарити. Играчи 
који показују малу варијацију брзине трчања са и без лопте имају велику предност у решавању ситација „једана на један“, ефикасног освајања простора са лоптом као и решавања ситуација „под притиском“ од стране противничких играча. Ове карактеристике су одлика изразито талентованих фудбалера и, пре свега, технички обучених појединаца. Према томе, резултати ових истражи-

\section{ЛИТЕРАТУРА}

1. Abbott, A., Button, C., Pepping, G., \& Collins, D. (2005). Unnatural Selection: talent identification and development in sport. Nonlinear dynamics, psychology and life Sciences, 9(1), 61-88.

2. Алексић, В., и Јанковић, А. (2006). ФуДБАЛ: Истиорија-Теорија-Мейоgика. Београд: Факултет спорта и физичког васпитања.

3. Bangsbo, J. (2003). Fitness training in soccer: A scientific approach. Spring City: Reedswain.

4. Bompa, O.T. (2000). Cjelokupan trening za mlade pobjednike. Zagreb: Gopal

5. Vaeyens, R., Malina, R.M., Janssens, M., Van Renterghem, B., Bourgois, J., Vrijens, J., \& Philippaerts, R.M. (2006). A multidisciplinary selection model for youth soccer: the Ghent Youth Soccer Project. British Journal of Sports Medicine, 40, 928-934.

6. Williams, M., \& Reilly, T. (2000). Talent identification and development in soccer. Liverpool: John Moores University.

7. Grant, A.G., Williams, A.M., \& Reilly, T. (1999) Analysis of the goals scored in the 1998 World Cup. Journal of Sports Sciences 17, 826-827.

8. Di Salvo, V., Baron, R., Tschan, H., Calderon Montero, F.J., \& Pigozzi, F. (2007). Motion Characteristics in Elite Level Soccer. International Journal of Sports Medicine, 28(3), 222-227.

9. Zubillga, A., \& Gorospe, G. (2007). Match analysis of 2005-06 Champions League Final with Amisco system. In Reilly and Korkusuz. Science and football VI: the proceedings of the Sixth World Congress on Science and Football (pp. 267-272). London: Routledge.

10. Јанковић, А., и Леонтијевић, Б. (2008). Структура техничко такмичарске активности у са- вања су управо потврдили претпоставку према којој је успјешност у фудбалу директно везана за ниво техничких способности, у овом примеру, директно са техником вођења лопте. Развој и усавршавање овога техничког елемента је један од главних циљева тренинга младих фудбалера, а у прилог овој констатацији иду и добијени резултати овога истраживања.

временом фудбалу. Физичка кулитура, 62(1-2) 159-169.

11. Јанковић, А., и Леонтијевић, Б. (2009): Анализа примене појединих техничких елемената у фудбалу у зависности од позиције играча у тиму. Физичка кулитура, 63(1), 76-88.

12. Jukić, I., Milanović, D., Marković, G., Milanović, L., Šimek, S., \& Gregov, C. (2007). Scientific and practical approach to physical conditioning of athletes. Serbian Journal of Sports Sciences, 1 (4), 116-112.

13. Malina, R.M., Cumming, S.P., Kontos, A.P., Eisenmann, J.C., Ribeiro, B., \& Aroso, J. (2005). Maturity-associated variation in sport-specific skills of youth soccer players aged 13-15 years. Journal of Sports Sciences, 23(5), 515-522.

14. Радосав, Р., Молнар, С., и Смајић, М. (2003). Теорија и метиоgика фуgбала. Нови Сад: Факултет физичке културе.

15. Reilly, T., Bangsbo, J., \& Franks, A. (2000a): Antropometric and physiological predispositions for elite soccer, Journal of Sports Sciences, 18, 669683.

16. Reilly, T,, Williams, A.M., Nevill, A. \& Franks, A. (2000b). A multidisciplinary approach to talent identification in soccer. Journal of Sport Sciences, 18 (9), 695-702.

17. Rosch, D., Hodgson, R., Peterson, L., Graf-Baumann, T., Junge, A., Chomiak, J., \& Dvorak J. (2000). Assessment and evaluation of football performance. American Journal of Sports Medicine, 28, 29-39.

18. Hoff, J., Wisloff, U., Engen, L., Kemi, O., \& Helgerud, J. (2002). Soccer specific aerobic endurance training, British Journal of Sports Medicine, $36,218-221$. 


\title{
EMPFINDLICHKEIT VON TESTS FÜR DIE EINSCHÄTZUNG DER GESCHWINDIGKEIT DER BALLFÜHRUNG BEI FUßBALLSPIELERN IM JUGENDALTER
}

\begin{abstract}
Zusammenfassung:
Ziel der Untersuchung war die Erkundung der Testempfindlichkeit für die Einschätzung der Geschwindigkeit der Ballführung. An der Untersuchung nahmen 76 Prüflinge männlichen Geschlechts im Alter von 17 Jahren teil ( \pm 6 Monate), die in zwei, im qualitativen Sinne unterschiedliche Untergruppen eingeteilt wurden. Für die Feststellung der Geschwindigkeit der Ballführung wurden Tests der Ballführung durch Kegel hindurch („M“-Ballführung) und der Ballführung durch Slalom mit Ballabgabe und -annahme durchgeführt. Anhand der gewonnenen Ergebnisse wurde festgestellt, dass Prüflinge aus der aus erfolgreicheren Fußballspielern bestehenden Gruppe (Gruppe 1) bei den angewendeten Tests bessere Ergebnisse erzielten als Prüflinge aus der Gruppe, die aus Fußballspielern zusammengesetzt war, die für schlechter rangierte Teams spielen und keine Mitglieder von repräsentativen Mannschaften sind (Gruppe 2). Hohe Werte der Ergebnishomogenität bei diesen beiden Gruppen der Prüflinge (Homogenität der Gruppe 1 beträgt 75\%, der Gruppe 2 68,75\%) weisen auf die Schlussfolgerung hin, dass diese Fertigkeit eine wichtige Charakteristik junger Fußballspieler darstellt. Der Diskriminierungskoeffizient von 0,269 für Ergebnisse des „M“-Tests für Ballführung und 0,197 für Ergebnisse des Tests der Ballführung mit Ballabgabe und -annahme weisen darauf hin, dass durch die Ergebnisse dieser beiden Tests im qualitativen Sinne junge Fußballspieler unterschieden werden können. In Einklang mit den gewonnenen Ergebnissen kann festgestellt werden, dass Ballführung als technisches Element einen bedeutenden Einfluss auf die Qualität des Spiels der Fußballspieler ausübt.
\end{abstract}

Schlüsselwörter: FUßBALL / TECHNIK / BALLFÜHRUNG / GESCHWINDIGKEIT / JUGENDLICHE

Примљен: 11.04.2016.

Прихваћен: 02.11.2016.

(c) 2016 Autor. Objavio Fizička kultura (www.fizickakultura.com). Ovo je članak otvorenog pristupa i distribuira se u skladu sa Creative Commons licencom (http://creativecommons.org/licenses/by/3.0/rs/). 